\title{
Evaluation of Blood Banked Fibrin Glue versus Blood Banked Platelet Glue as a Local Hemosatic Agent and a Healing Promoter in Patients with Acute Leukemia Undergoing Tooth Extraction
}

\author{
Suzan Salem ${ }^{1^{*}}$ and Islam Saad ${ }^{2}$ \\ ${ }^{1}$ Department of Oral Maxillofacial and Diagnostic Science, College of Dentistry, Qassim University, \\ KSA. \\ ${ }^{2}$ Department of Periodontology and Oral Medicine, College of Dentistry, Qassim University, KSA.
}

\section{Authors' contributions}

This work was carried out in collaboration between both authors. Author SS designed the study, performed the statistical analysis, wrote the protocol and wrote the first draft of the manuscript. Author

IS corrected the minor change in the second draft. Both authors read and approved the final manuscript.

Article Information

DOI: 10.9734/BJMMR/2017/33470

Editor(s):

(1) Ibrahim El-Sayed M. El-Hakim, Ain Shams University, Egypt and Riyadh College of Dentistry and Pharmacy, Riyadh,

Saudi Arabia

(2) Salomone Di Saverio, Emergency Surgery Unit, Department of General and Transplant Surgery, S. Orsola Malpighi

University Hospital, Bologna, Italy

Reviewers:

(1) Atanaska Dinkova, Plovdiv Medical University, Bulgaria.

(2) Sujeet V. Khiste, MGM Dental college and hospital, Kamothe, India

(3) Gaetano Marenzi, Univesity of Naples "Federico ii", Italy.

(4) José Francisco Gómez Clavel, School of Higher Studies (F.E.S.) Iztacala, National Autonomous University of Mexico,

México.

(5) Wagih Mommtaz Ghannam, Mansoura faculty of Medicine, Mansoura University, Egypt. Complete Peer review History: http://www.sciencedomain.org/review-history/19119

Original Research Article

Received $17^{\text {th }}$ April 2017

Accepted $16^{\text {th }}$ May 2017

Published $18^{\text {th }}$ May 2017

\begin{abstract}
Aims: The purpose of this study was to compare the effectiveness of blood banked platelet glue and blood banked fibrin glue as a local hemostatic agent after tooth extraction in patients diagnosed with acute leukemia with concomitant thrombocytopenia.

Study Design: Randomized clinical trial.

Place and Duration of Study: Hematology Unit, Internal Medicine Department, Faculty of Medicine, Alexandria University, Alexandria, Egypt between June 2015 and July 2016.

Methodology: 21 patients who underwent 60 dental extractions diagnosed with acute leukemia
\end{abstract}


with concomitant thrombocytopenia; age between 25-45 years were included in this study. Patients were randomly allocated into three groups: Group I (control group) patients had underwent platelet transfusion before tooth extraction and was continued after the extraction if re-bleeding occurred, Group II (Fibrin Group) Fibrin glue used as a local hemostatic agent after tooth extraction; and Group III (Platelet group) platelet glue used as a local hemostatic agent after tooth extraction. Immediate and delayed evaluation by monitoring time to hemostasis (secs), postoperative complications; fever, localized gingival inflammation, disintegrated blood clot, wound dehiscence, wound infection and time in days for healing.

Statistical software SPSS v.17.0 was used for statistical analysis.

Results: Time to hemostasis (secs) was $12.57 \pm 1.51 \mathrm{sec}, 9.57 \pm 2.57 \mathrm{sec}$, and $9.43 \pm 2.44 \mathrm{sec}$ for group I, II and III respectively, significant difference at $\mathrm{P}$ - value $(\mathrm{P} \leq 0.05)$ was found between three groups. Wound healing time was $16.00 \pm 3.51$ days, $10.00 \pm 1.00$ days and $7.29 \pm 0.95$ days in Group I, Group II and Group III respectively, significant difference at $P$ - value $(P \leq 0.05)$ was found between three groups.

Conclusion: Blood banked platelet glue has excellent hemostatic action and can be used successfully as a local hemostasis after tooth extraction.

Keywords: Acute leukemia; fibrin glue; platelet glue; thrombocytopenia; tooth extraction.

\section{INTRODUCTION}

Systemic medical conditions can effect on the oral health and dental treatment required for medically compromised patients. Dental management of these patients can be problematic in terms of oral complications, dental treatment, and emergency care which require a thorough medical history before planning a safe dental treatment [1]. Dental disorders have been recognized as major sources of infection in patients with leukemia [2]. Most signs and symptoms of Leukemia had been attributed to increased number of malignant white blood cells, which displace or otherwise interfere with production of normal blood cells in the bone marrow, resulting in lack of normal white blood cell production makes the patient susceptible to infections, lack of red blood cells (anemia) can cause fatigue, pallor, and shortness of breath and lack of platelets (thrombocytopenia) lead to easy bruising or bleeding with minor trauma, such as petechiae, ecchymosis, epistaxis, melena, increased menstrual bleeding, and gingival bleeding, when the platelet count falls below $25,000 / \mathrm{mm}^{3}$ [3]. Platelet transfusion should be considered in patients with thrombocytopenia who are actively bleeding or who are at risk of bleeding [4]. The number of platelet units to be transfused should be determined on a casespecific manner. Theoretically, the required number of units can be estimated according to the patient's body surface area or blood volume. Complications of platelet and blood product transfusion should be reviewed preoperative with patients. Common risks such as bacterial and viral infections and allergic reactions should be emphasized. The patient should understand the risk of a reaction or infection per unit transfused: allergic or febrile reactions, 1:400; hepatitis C infection, 1:103,000; hepatitis B infection, 1:200,000; and HIV infection, 1:409,000 [5]. Throughout the literature review, minor attention was given as how to manage bleeding problems locally in minor oral surgery for this group of patients which may have altered clotting function. Certain local hemostatic measures were suggested to be sufficient to control operative bleeding in patients undergoing minor oral surgery and suffering from altered clotting function without the need of using systemic replacement therapy [6]. Mixing fibrinogen and thrombin mimics the last step of the blood coagulation cascade, resulting in the formation of a semi-rigid to rigid fibrin clot that consolidates and adheres to the application site and acts as a fluid-tight sealing agent able to stop bleeding and hold tissues and materials in a desired configuration, this mix known as fibrin glue. It was found that fibrin glue has a hemostatic, sealing, and healing properties in addition to its biocompatibility, biodegradability, and the absence of induction of inflammatory reactions or tissue necrosis over synthetic surgical glues include [7]. The use of commercially available fibrin glue where bovine thrombin may carry the risk of inducing immunological reactions (formation of cross reactive anti-factor $\mathrm{V}$ or anti-thrombin antibodies) in patients and concerns over the transmission of bovine infectious agents, such as Bovine Spongiform Encephalopathy have been raised and so another form of fibrin glue was introduced where 
the bovine thrombin was replaced with human thrombin [8].

In 2003 Weibrich G et al. [9], pre-mixed plateletrich blood fraction with fibrinogen, which later mixed with thrombin produced a product referred as "platelet glue", which had better adhesive properties and higher resistance to body fluids and pressure than platelet gel. The use of platelets has a double benefit; the first is acting as a local hemostatic, thus helping clotting function and the second, is aiding in the healing of tissues by secreting healing and growth factors which enhance recovery [8].

The purpose of this study was to investigate the efficacy of using blood banked (BP) Platelet glue as a local hemostatic agent and healing promoter after tooth extraction in patients diagnosed with acute leukemia with concomitant thrombocytopenia.

\section{MATERIALS AND METHODS}

\subsection{Participant and Procedures}

Twenty-one patients who underwent 60 dental extractions (36 maxillary teeth and 24 mandibular teeth) and diagnosed with acute leukemia from Hematology Unit, Internal Medicine Department, Faculty of Medicine, Alexandria University were included in this study. Patients were selected according to the presence of one or more tooth indicated for extraction. The selection criteria were based on the following criteria; all Patients with Acute leukemia (Acute lymphoblastic leukemia or Acute myeloid leukemia) suffering from thrombocytopenia (platelet count not less than $50,000 / \mathrm{mm}^{3}$ ), age range from $25-45$ years with mean of age 33.57 years from both sexes where males predominated since 16 patients were males and 5 were females (Table 1). All patients were selected in the post induction phase of chemotherapy treatment.

Patients were randomly allocated into three groups using simple random sample according to the procedure used to control bleeding; Group I (control group): seven patients who underwent 20 dental extractions (12 maxillary teeth and 8 mandibular teeth) had undergone platelet transfusion one hour before tooth extraction and was continued after the extraction if re-bleeding occurred, Group II (Fibrin group): seven patients who underwent 20 dental extractions (12 maxillary teeth and 8 mandibular teeth) received blood banked Fibrin glue (Dr M. Al-Shabrawishi Hospital Blood Bank, Egypt) as a local hemostatic agent after tooth extraction.
The Fibrin glue is supplied in two separate syringes, one containing human Fibrinogen and the second containing human Thrombin prepared from single donor plasma in sterile disposables under aseptic precautions.

Group III (Platelet group): Seven patients who underwent 20 dental extractions (12 maxillary teeth and 8 mandibular teeth) received blood banked platelet glue ( $\mathrm{Dr}$ M. Al-Shabrawishi Hospital Blood Bank, Egypt) as a local hemostatic agent after tooth extraction.

The platelet glue is supplied in three separate syringes, one containing human platelets, the second human Fibrinogen and the third human Thrombin prepared from single donor plasma in sterile disposables under aseptic precautions.

Fibrinogen and Thrombin syringes stored frozen in blood banks at $-70^{\circ} \mathrm{C}$ for 3 months, while the platelet syringe stored at room temperature on shaker.

\subsubsection{Preoperative phase}

The following laboratory investigations were monitored and performed:

- Complete Blood Picture (CBC) including Platelet count not less than $50,000 / \mathrm{mm}^{3}$ and differential blood count with absolute neutrophils count (ANC) not less than $1000 / \mathrm{mm}^{3}$.

- Blood biochemistry (liver and kidney function).

- Blood grouping.

- Prothrombin time, partial thromboplastin time, INR (International Normalized Ratio), and bleeding, and clotting times were performed 24 to 48 hours before dental extraction. Only patients with INR values less than 2.5 and PT less than 20 seconds were selected for dental extraction. Hemostasis was exclusively relied on the local measures to control operative and postoperative bleeding without using any systemic replacement therapy.

- Immunophenotyping by Flowcytometry to determining whether the leukaemia is lymphoid or myeloid.

- Bone marrow aspiration was monitored from the patient's file for diagnosis of leukemia.

- Hepatitis marker for HBV and HCV. 
- All patients were given prophylaxis antibiotics one hour before procedures [10].

A detailed written consent form in Arabic language was explained to every patient for his or her signed approval to the procedures performed as regards to the use of blood banked platelet glue in the extraction socket following dental extraction.

Aseptic surgical technique and universal infection control precautions were used during the whole procedure.

\subsubsection{Operative phase}

All patients were given local anaesthetic as Mepivacaine HCL $2 \%$.

The method of performing tooth extraction for the study and the control group was as follows:

\subsubsection{Group I}

All patients had undergone platelet transfusion one hour before tooth extraction. After performing the extraction, a gauze pack was then placed on the socket in the usual manner.

\subsubsection{Group /I}

After tooth extraction, the socket is isolated with a surgical dressing and a dry gauze pack was placed inside the socket while the local hemostatic agent was being prepared.

The two syringes, one containing human fibrinogen and the second containing human thrombin were thawed at $37^{\circ} \mathrm{C}$ in water bath until the two components become liquid at the operation time, then the two syringes were placed in the applicator to be applied into the isolated socket immediately after removing the gauze from the socket till coagulation occurs and patients were kept under observation for 2 hours.

\subsubsection{Group III}

After tooth extraction, the socket is isolated with a surgical dressing and a dry gauze pack was placed inside the empty socket while the local hemostatic agent was being prepared.

The platelet-rich blood fraction pre-mixed with human fibrinogen, then mixed with human thrombin. The product is supplied in three syringes.

First the human fibrinogen syringe and human thrombin syringe were thawed at $37^{\circ} \mathrm{C}$ in water bath until the two components become liquid at the operation time, then the platelet syringe was mixed with the fibrinogen and both components were collected in one syringe which was placed in the applicator with the human thrombin syringe. The platelet glue was ready to be applied into the isolated socket immediately after removing the gauze from the socket till coagulation occur and patients were kept under observation for 2 hours.

\subsubsection{Postoperative phase}

Oral antibiotics Augmentin (Kline Beecham Pharmaceuticals, England) was prescribed 1gm every 12 hours for one week.

For pain and fever control, analgesic, antipyretic drugs were prescribed; paracetamol 500mg (Misr Co. for Pharm IND. S.A.E) 3 times daily for 5 days.

$0.12 \%$ chlorhexidine gluconate mouth wash (Antiseptol mouthwash, Kahira Pharmaceuticals and Chemical Industries co., Egypt) three times daily in the second postoperative day and to be continued for one week.

Table 1. Comparison among groups as regards age, sex and type of leukemia

\begin{tabular}{lllll}
\hline Features & & $\begin{array}{l}\text { Group I } \\
\text { Control }\end{array}$ & $\begin{array}{l}\text { Group II } \\
\text { Fibrin }\end{array}$ & $\begin{array}{l}\text { Group III } \\
\text { Platelet }\end{array}$ \\
\hline Age & Mean \pm SD & $35.1 \pm 7.8$ & $33.4 \pm 7.8$ & $34.43 \pm 9.0$ \\
Sex & Male: $n$ & 7 & 4 & 5 \\
& Female: $\mathrm{n}$ & 0 & 3 & 2 \\
Type of leukemia & ALL: $\mathrm{n}$ & 1 & 2 & 1 \\
& AML: $\mathrm{n}$ & 6 & 5 & 6 \\
\hline
\end{tabular}


All patients were re-hospitalized after proper extraction instructions and were instructed to:

- Be in immediate contact if secondary hemorrhage took place in the first postoperative day.

- $\quad$ Not using mouthwash for at least 12 hours postoperative and after 12 hours using Tranexamic mouthwash "antifibrinolytic agent" for 4 days.

- Took analgesic medication as paracetamol for pain relief.

- Continue prophylactic antibiotics for 4 days.

- $\quad$ Avoid any hot food or drinks for the rest of the operational day to prevent re-bleeding, only cold fluids or soft food to avoid wound irritation.

- Avoid places of any objects at the wound site.

\subsection{Postoperative Evaluation}

\subsubsection{Immediate evaluation}

On the day of extraction, the patients were kept under close observation for two hours following extraction to evaluate and record the immediate condition of the surgical wound and the effectiveness of local hemostatic agents to control bleeding.

Life saving measures, if bleeding continues; platelet transfusion and anti-hemorrhagic agents "Tranexamic acid" (Kapron, Amoun Pharmaceutical Co) was ready to be given.

\subsubsection{Delayed evaluation}

The patient was followed up daily for 5 days postoperatively for, high temperature, local bleeding, healing and lymphadenitis.

\subsection{Radiographic Evaluation}

Periapical radiograph was taken at 6 and 12 weeks to evaluate post extraction socket healing.

\subsection{Statistical Analysis}

Descriptive statistics were displayed as means and standard deviations for quantitative variables (platelet count, INR, time in seconds to hemostasis, time in days to heal) and frequencies for qualitative variables (sex, type of leukemia, inflammation score and presence of lymphadenitis).
Comparison among the three groups as regards quantitative variables was done using analysis of variance. Statistically significant comparisons were followed by Tukey post hoc test for pairwise comparison among pairs of groups.

Comparison between platelet counts before and after intervention was done using paired t test. Similarly, the comparison between temperature between first and fifth days was done using paired t test.

Comparison among the three groups as regards qualitative nominal variables (sex, type of leukemia, presence of lymphadenitis) were done using chi square test. Comparison of lymphadenitis presence in the same group between the first and fifth days was done using McNemar test.

Comparison among the three study groups as regards qualitative ordinal variables (inflammation score) was done using a Kruskal Wallis test. Comparison of these scores in the same group between the first and fifth days was done using Wilcoxon signed rank test.

INR values were categorized into normal $<1.3$ and abnormal > 1.3 and the differences among the three groups in the distribution of the produced variable was done using chi square test.

Graphical presentation was done using bar charts, clustered bar charts and line.

The significance level was set at 5\%. Statistical analysis was done using SPSS version 17.0.

\section{RESULTS AND DISCUSSION}

\subsection{Results}

The recruitment target of 21 patients, which corresponded to 60 tooth extraction was reached in about 1 years. Complete blood picture was done for 3 days to monitor any sudden changes in the platelet count that indicate the need for platelet transfusion.

All patients were followed up daily for 5 days postoperatively for clinical examination and evaluation of the presence of any postoperative complications, including: fever, localized gingival inflammation, disintegrated blood clot, wound dehiscence, wound infection, and to assess socket closure and healing. 
Table 2 Chart 1 , shows the mean platelet counts, INR and times is seconds for hemostasis. The mean platelet counts for all patients before undergoing tooth extraction was $157,714.3 \pm 3,903.60,73,714.29 \pm 11,353.62$ and $82,857.14 \pm 13,969.35$ for group I, II and III respectively, although this difference is statistically significant but it has no correlation to our study. The mean time in seconds to hemostasis was $12.57 \pm 1.51,9.57 \pm 2.57$ and $9.43 \pm 2.44$ for group I, II and III respectively, over the follow up period, the difference between the three groups was statistically significant $(p=0.03)$.
Table 3 and Chart 1 shows comparison between all groups as regards inflammation over the five days of observation. In groups II and III, all cases showed no inflammation starting from the $3^{\text {rd }}$ day, whereas only four cases in group I were free from inflammation on the $5^{\text {th }}$ day. Moderate inflammation persisted in two cases in group I starting from the $3^{\text {rd }}$ day. The differences among the three study groups were statistically significant on the $1^{\text {st }}, 2^{\text {nd }}, 3^{\text {rd }}$ and $4^{\text {th }}$ days $(P=0.03,0.04,0.002$ and 0.002 respectively). Only in groups II and III there were significant differences between inflammation scores on the $1^{\text {st }}$ and $5^{\text {th }}$ days $(\mathrm{P}=0.02$ and 0.001 respectively).

Table 2. Comparison between the three groups regarding platelet counts, INR, time in second to hemostasis and time in days for healing

\begin{tabular}{lllll}
\hline & $\begin{array}{l}\text { Group I } \\
\text { Control }\end{array}$ & $\begin{array}{l}\text { Group II } \\
\text { Fibrin }\end{array}$ & $\begin{array}{l}\text { Group III } \\
\text { Platelet }\end{array}$ & P value \\
\hline Platelet counts & $157,714.3 \pm 3,903.60^{\mathrm{b}}$ & $73,714.29 \pm 11,353.62^{\mathrm{a}}$ & $82,857.14 \pm 13,969.35^{\mathrm{a}}$ & $<0.0001^{*}$ \\
INR & $1.07 \pm 0.13^{\mathrm{N}}$ & $1.41 \pm 0.37$ & $1.26 \pm 0.24$ & $0.09^{\mathrm{a}}$ \\
Time in secs to & $12.57 \pm 1.51^{\mathrm{D}}$ & $9.57 \pm 2.57^{\mathrm{a}}$ & $9.43 \pm 2.44^{\mathrm{a}}$ & $0.03^{*}$ \\
hemostasis $^{*}$ & & & & \\
\hline
\end{tabular}

$a, b$ : different letters denoting statistically significant differences

Table 3. Comparison between the three groups as regards inflammation over the five days of observation

\begin{tabular}{|c|c|c|c|c|c|c|c|c|c|c|c|c|c|c|c|}
\hline \multirow{2}{*}{ 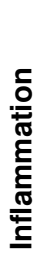 } & \multicolumn{3}{|c|}{ Day 1} & \multicolumn{3}{|c|}{ Day 2} & \multicolumn{3}{|c|}{ Day 3} & \multicolumn{3}{|c|}{ Day 4} & \multicolumn{3}{|c|}{ Day 5} \\
\hline & $\begin{array}{l}\overline{ } \\
\text { 을 } \\
\text { 인 }\end{array}$ & $\begin{array}{l}= \\
\overline{0} \\
\frac{2}{3} \\
\text { 인 }\end{array}$ & $\begin{array}{l}\equiv \\
\text { 을 } \\
\text { 인 }\end{array}$ & $\begin{array}{l}\overline{ } \\
\frac{0}{3} \\
\text { 인 }\end{array}$ & $\begin{array}{l}= \\
\overline{0} \\
\frac{0}{3} \\
\text { 인 }\end{array}$ & $\begin{array}{l}\equiv \\
\equiv \\
\frac{0}{3} \\
\text { 인 }\end{array}$ & $\begin{array}{l}\overline{0} \\
\frac{0}{3} \\
\text { 인 }\end{array}$ & $\begin{array}{l}= \\
\overline{0} \\
\text { 을 } \\
\text { 인 }\end{array}$ & 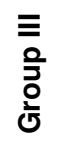 & $\begin{array}{l}\overline{ } \\
\text { 을 } \\
\text { 은 }\end{array}$ & $\begin{array}{l}= \\
\overline{0} \\
\text { 을 } \\
\text { o는 }\end{array}$ & $\begin{array}{l}\equiv \\
\text { 三을 } \\
\text { 인 }\end{array}$ & $\begin{array}{l}\overline{0} \\
\text { 을 } \\
\text { 은 }\end{array}$ & $\begin{array}{l}= \\
\overline{0} \\
\text { 은 } \\
\text { 는 }\end{array}$ & $\begin{array}{l}\equiv \\
\overline{0} \\
\frac{0}{3} \\
\text { 인 }\end{array}$ \\
\hline $\begin{array}{l}\text { 0 } \\
\text { 을 }\end{array}$ & 0 & 2 & 0 & 0 & 5 & 6 & 1 & 7 & 7 & 1 & 7 & 7 & 4 & 7 & 7 \\
\hline 을 & 2 & 4 & 7 & 5 & 2 & 1 & 4 & 0 & 0 & 4 & 0 & 0 & 1 & 0 & 0 \\
\hline 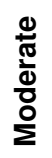 & 3 & 1 & 0 & 1 & 0 & 0 & 2 & 0 & 0 & 2 & 0 & 0 & 2 & 0 & 0 \\
\hline ڤ & 2 & 0 & 0 & 1 & 0 & 0 & 0 & 0 & 0 & 0 & 0 & 0 & 0 & 0 & 0 \\
\hline$\frac{0}{\frac{0}{\pi}}$ & & $\begin{array}{l}14.42 \\
0.03^{*}\end{array}$ & & & $\begin{array}{l}12.89 \\
0.04^{*}\end{array}$ & & & $\begin{array}{l}16.80 \\
0.002^{*}\end{array}$ & & & $\begin{array}{l}16.80 \\
0.002^{*}\end{array}$ & & & $\begin{array}{l}7.00 \\
0.14\end{array}$ & \\
\hline
\end{tabular}




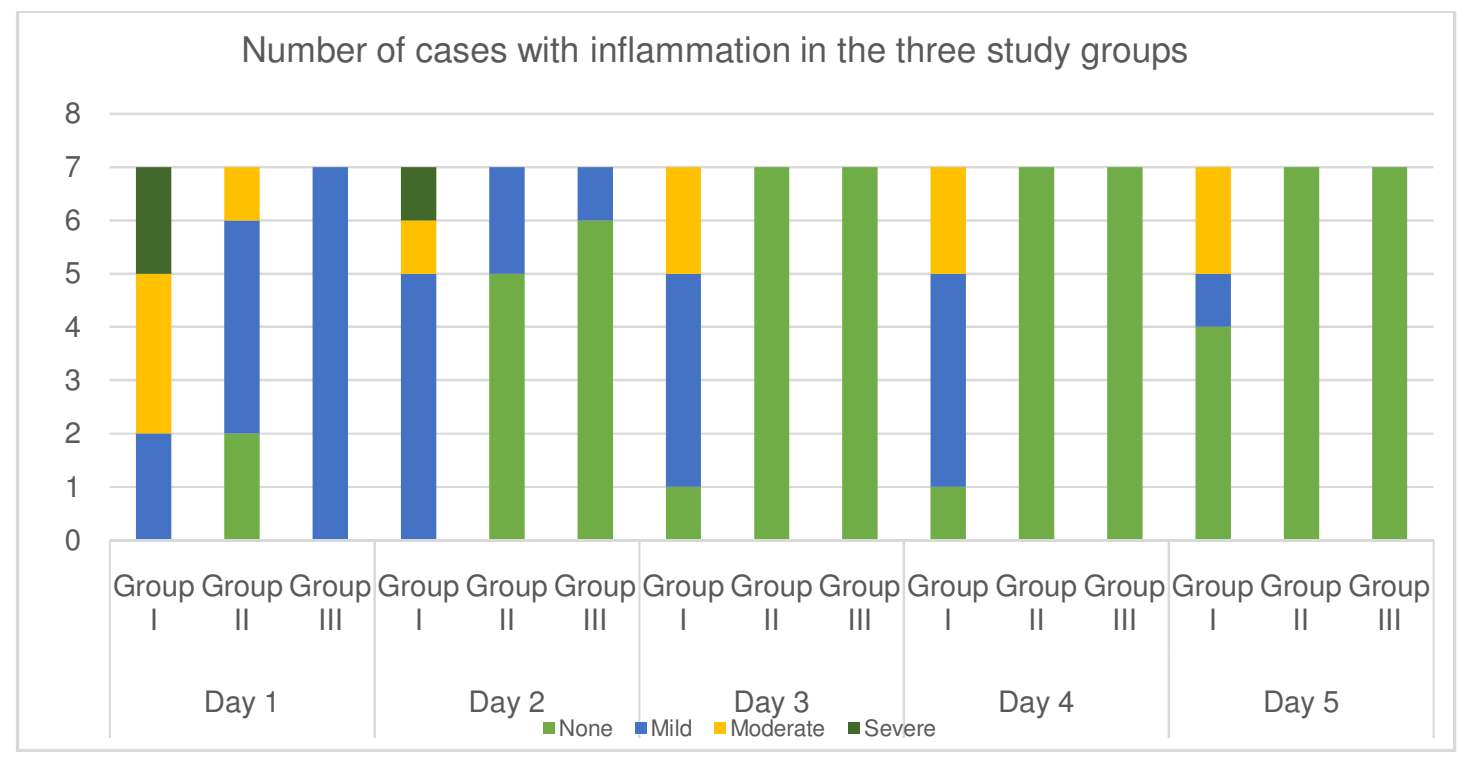

\section{Chart 1. Comparison between the three groups as regards inflammation over the five days of observation}

Table 4 and Chart 2 shows comparison between study groups as regards lympadenitis over the five days of observation. In groups II and III, all cases showed no lymphadenitis starting from the $3^{\text {rd }}$ day, whereas five cases in group I were free from lymphadenitis on the $5^{\text {th }}$ day. Lympadenitis persisted in two cases in group I starting from the $4^{\text {th }}$ day. The differences among the three study groups were statistically significant on the $1^{\text {st }}, 2^{\text {nd }}$ and $3^{\text {rd }}$ days $(P=0.01,0.01$ and 0.03 respectively). No statistically significant differences were observed in groups I, II and III between presence of lympadenitis on the $1^{\text {st }}$ and $5^{\text {th }}$ days $(P=0.11,1.00$ and 1.00 respectively).

Table 4. Comparison between the two groups as regards lymphadenitis over the five days of observation

\begin{tabular}{|c|c|c|c|c|c|c|c|c|c|c|c|c|c|c|c|}
\hline \multirow{2}{*}{ 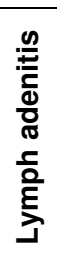 } & \multicolumn{3}{|c|}{ Day 1} & \multicolumn{3}{|c|}{ Day 2} & \multicolumn{3}{|c|}{ Day 3} & \multicolumn{3}{|c|}{ Day 4} & \multicolumn{3}{|c|}{ Day 5} \\
\hline & $\begin{array}{l}\overline{0} \\
\text { оे } \\
\text { ơ }\end{array}$ & $\begin{array}{l}\overline{=} \\
\stackrel{0}{0} \\
\overline{0} \\
\text { Ū }\end{array}$ & $\begin{array}{l}\equiv \\
\text { 음 } \\
\text { o }\end{array}$ & 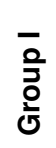 & $\begin{array}{l}\overline{=} \\
\stackrel{0}{3} \\
\overline{0} \\
\bar{U}\end{array}$ & 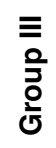 & $\begin{array}{l}\overline{0} \\
\text { ơ } \\
\text { ơ }\end{array}$ & $\begin{array}{l}\overline{0} \\
\stackrel{0}{3} \\
\overline{0} \\
\bar{U}\end{array}$ & 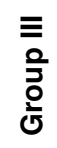 & $\begin{array}{l}\overline{0} \\
\text { Oे } \\
\text { ơ }\end{array}$ & $\begin{array}{l}\overline{\overline{0}} \\
\text { 응 } \\
\text { ò }\end{array}$ & $\begin{array}{l}\equiv \\
0 \\
\frac{0}{0} \\
\text { 인 }\end{array}$ & $\begin{array}{l}\overline{0} \\
\text { Oे } \\
\text { ơ }\end{array}$ & $\begin{array}{l}\overline{=} \\
\frac{0}{3} \\
\frac{0}{\dot{U}}\end{array}$ & 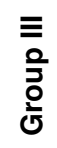 \\
\hline 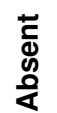 & 1 & 6 & 6 & 3 & 7 & 7 & 4 & 7 & 7 & 5 & 7 & 7 & 5 & 7 & 7 \\
\hline
\end{tabular}

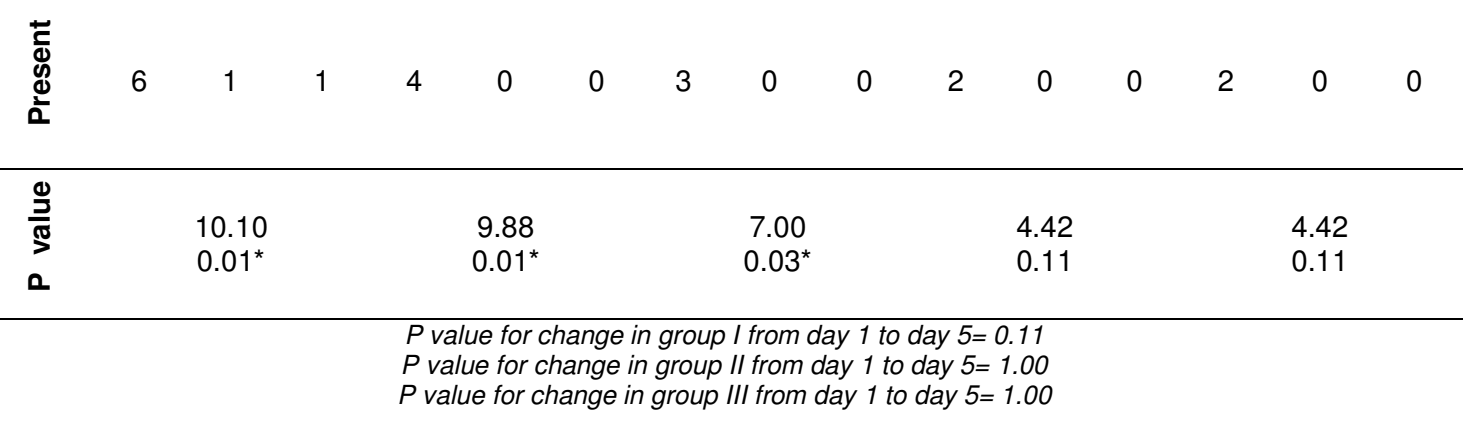




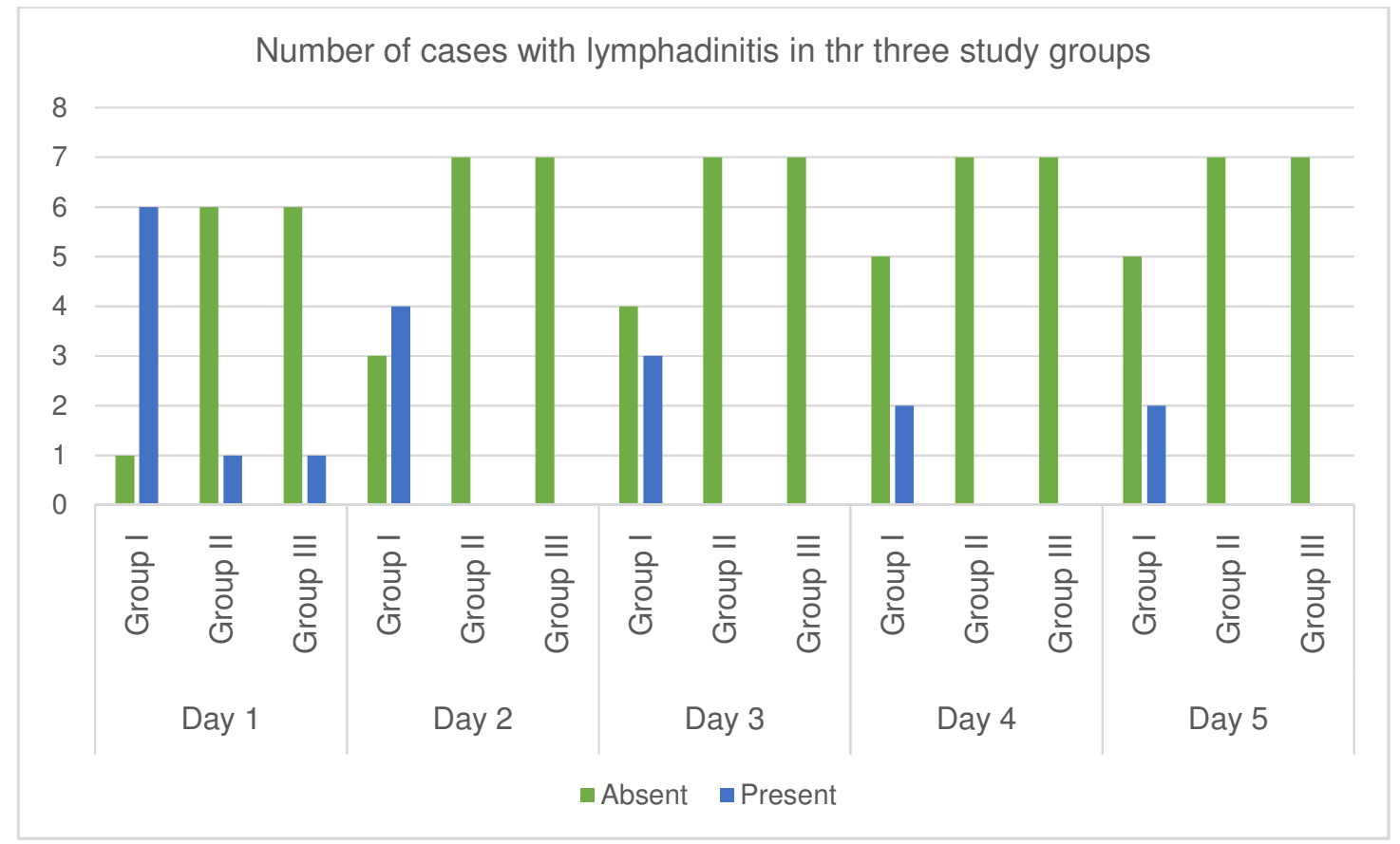

Chart 2. Number of cases with lymphadentitis in the three groups over the five days of observation

Table 5 and Graph 1 shows the comparison between all groups as regards temperature over the five days of observation. In the three study groups, temperature decreased between the $1^{\text {st }}$ and $5^{\text {th }}$ day. This drop in temperature was statistically significant between groups I and II $\left(P=0.01\right.$ and 0.01 respectively). Only on the $2^{\text {nd }}$ and $3^{\text {rd }}$ days the differences between the three groups was statistically significant $(P=0.03$ and 0.04 respectively).

Table 5. Comparison between the three groups as regards temperature over the five days of observation

\begin{tabular}{|c|c|c|c|c|c|c|c|c|c|c|c|c|c|c|c|}
\hline \multirow{2}{*}{ 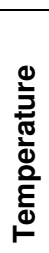 } & \multicolumn{3}{|c|}{ Day 1} & \multicolumn{3}{|c|}{ Day 2} & \multicolumn{3}{|c|}{ Day 3} & \multicolumn{3}{|c|}{ Day 4} & \multicolumn{3}{|c|}{ Day 5} \\
\hline & $\begin{array}{l}\overline{0} \\
\frac{0}{3} \\
\text { 분 }\end{array}$ & $\begin{array}{l}= \\
\text { 을 } \\
\text { 인 }\end{array}$ & $\begin{array}{l}\text { 三 } \\
\text { 윽 } \\
\text { 인 }\end{array}$ & $\begin{array}{l}\bar{a} \\
\text { 을 } \\
\text { 닌 }\end{array}$ & 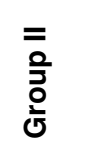 & 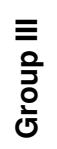 & $\begin{array}{l}\overline{0} \\
\frac{0}{3} \\
\overline{0}\end{array}$ & $\begin{array}{l}\overline{=} \\
\text { 을 } \\
\text { 인 }\end{array}$ & $\begin{array}{l}\equiv \\
\text { 을 } \\
\text { 인 }\end{array}$ & $\begin{array}{l}\bar{a} \\
\text { 을 } \\
\text { 닌 }\end{array}$ & 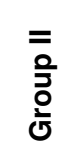 & $\begin{array}{l}\equiv \\
\text { 三윽 } \\
\text { 인 } \\
\text { U. }\end{array}$ & $\begin{array}{l}\overline{0} \\
\frac{0}{3} \\
\overline{0}\end{array}$ & 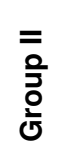 & $\begin{array}{l}\equiv \\
\overline{0} \\
\frac{0}{3} \\
\text { 인 }\end{array}$ \\
\hline $\begin{array}{l}\text { 0 } \\
+1 \\
+\frac{1}{\pi} \\
\stackrel{\Phi}{\Sigma}\end{array}$ & $\begin{array}{l}0 \\
0 \\
+1 \\
+ \\
\stackrel{0}{0} \\
\stackrel{m}{\infty}\end{array}$ & $\begin{array}{l}+ \\
0 \\
+1 \\
0 \\
0 \\
0\end{array}$ & $\begin{array}{l}0 \\
0 \\
+1 \\
+ \\
\dot{\sim} \\
\text { ஸे }\end{array}$ & $\begin{array}{l}\stackrel{+}{0} \\
+1 \\
\text { N } \\
\text { N }\end{array}$ & 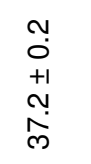 & $\begin{array}{l}\stackrel{+}{0} \\
+1 \\
\text { Dे. } \\
\stackrel{m}{m}\end{array}$ & $\begin{array}{l}0 \\
0 \\
+1 \\
0 \\
0 \\
\hat{m}\end{array}$ & $\begin{array}{l}\cong \\
0 \\
+1 \\
+ \\
\hat{m}\end{array}$ & 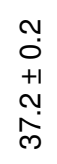 & $\begin{array}{l}\stackrel{+}{0} \\
+1 \\
+1 \\
\stackrel{m}{0}\end{array}$ & 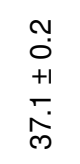 & $\begin{array}{l}\tilde{y} \\
0 \\
+1 \\
0 \\
0 \\
\hat{m}\end{array}$ & $\begin{array}{l}\text { Nִ } \\
0 \\
+1 \\
\\
\text { ஸे }\end{array}$ & $\begin{array}{l}\sigma \\
0 \\
+1 \\
\circ \\
\hat{N}\end{array}$ & $\begin{array}{l}0 \\
+1 \\
0 \\
\hat{N}\end{array}$ \\
\hline $\begin{array}{l}\frac{0}{2} \\
\frac{\pi}{>} \\
0\end{array}$ & & $\begin{array}{l}1.46 \\
0.26\end{array}$ & & & $\begin{array}{l}4.36 \\
0.03^{*}\end{array}$ & & & $\begin{array}{l}3.85 \\
0.04\end{array}$ & & & $\begin{array}{l}2.69 \\
0.10\end{array}$ & & & $\begin{array}{l}0.68 \\
0.52\end{array}$ & \\
\hline & & & & & for & & & fro & & & $\begin{array}{l}0.01^{*} \\
0.01^{*} \\
0.12\end{array}$ & & & & \\
\hline
\end{tabular}




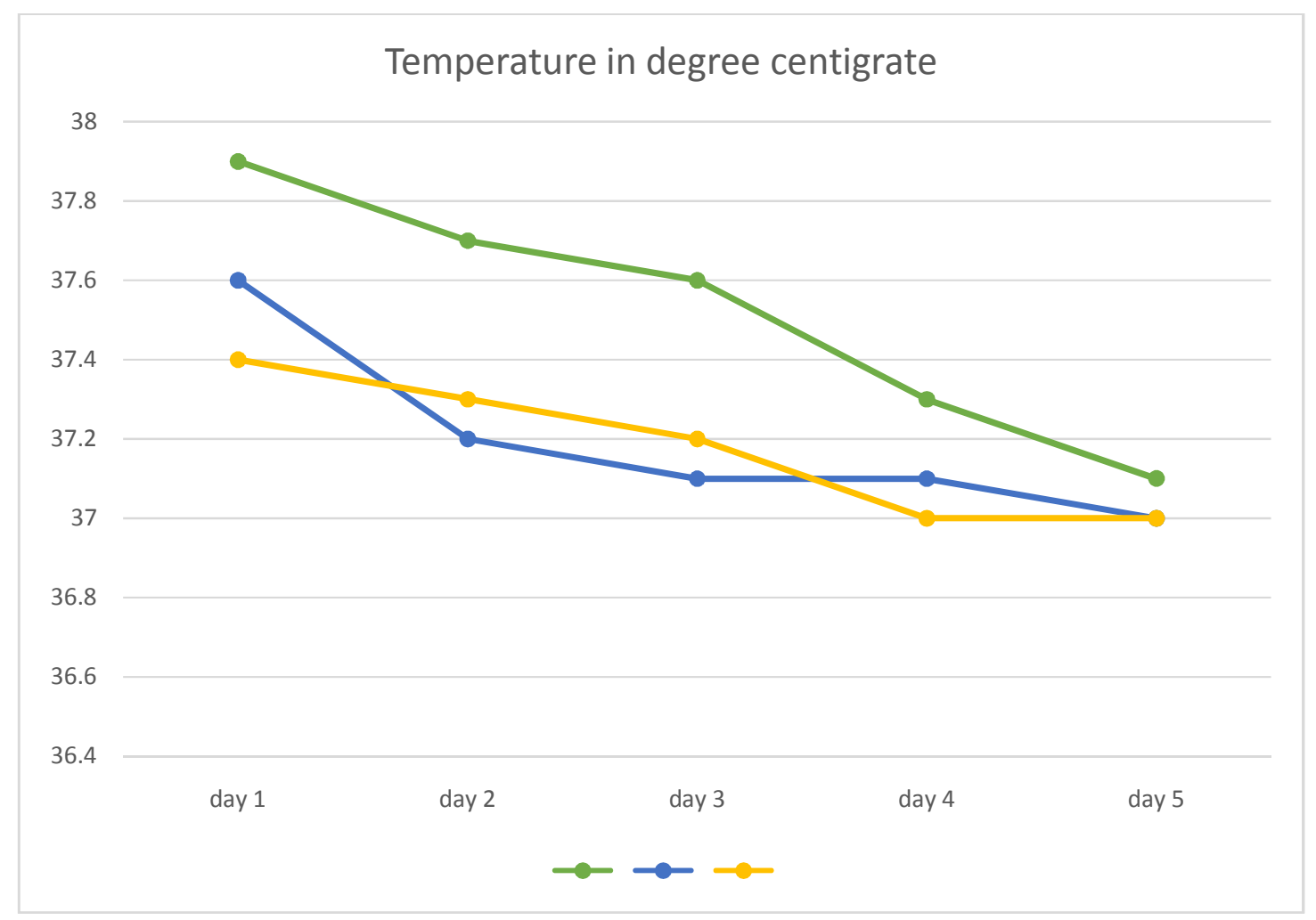

Graph 1. Temperature in degree centigrade over the five days of observation

Table 6 and Chart 3 shows the comparison among study groups as regards time in days to healing which was estimated by clinical examination of the wounds postoperatively for disintegrated clots, dehiscence of the wounds and signs of wound infection.

There were no signs of infection nor disintegrated clot nor wound dehiscence noticed in any of the patients of the two study groups, but there were signs of wound dehiscence and infected sockets in 1 patient in the group I.

However, socket closure for patients of the group I and group || showed signs of improved soft tissue healing and faster closure of the extraction sockets when compared to those extraction sockets of the control group during the first and second week postoperatively.

By the end of the third week, postoperative clinical assessment of all 21 patients had complete socket closure with good gingival healing and no signs of delayed wound healing were observed in any patient of either group. The mean time in days to healing was $16.00 \pm 3.51,10.00 \pm 1.00$ and $7.29 \pm 0.95$ for group I, II and III respectively, the difference was statistically significant between the three groups was statistically significant $(p=<0.0001)$.

Table 6. Comparison among the three groups as regards time in days to healing

\begin{tabular}{|c|c|c|c|}
\hline & $\begin{array}{l}\text { Group I } \\
\text { Control }\end{array}$ & $\begin{array}{l}\text { Group II } \\
\text { Fibrin }\end{array}$ & $\begin{array}{l}\text { Group III } \\
\text { Platelet }\end{array}$ \\
\hline Mean \pm SD & $16.00 \pm 3.51^{b}$ & $10.00 \pm 1.00^{a}$ & $7.29 \pm 0.95^{a}$ \\
\hline ANOVA & & 29.33 & \\
\hline$P$ value & & $<0.0001^{*}$ & \\
\hline
\end{tabular}




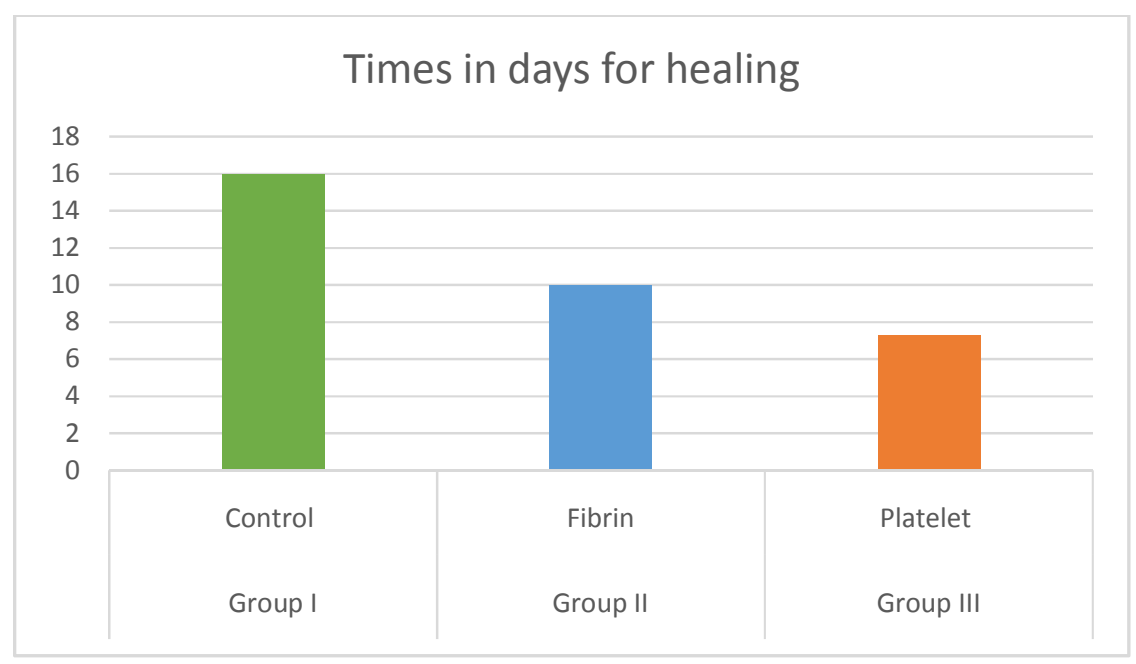

\section{Chart 3. Time in days for healing}

At the end of the three months follow up period clinical and radiological evaluations were performed and the results were as follows:

\section{A. Clinical evaluation:}

All patients presented normally with no signs or symptoms of any delayed socket healing.

All patients had complete soft tissue healing of the extraction sites with normal healthy gingival tissue. Furthermore, many healed wounds showed signs of well contoured edentulous alveolar ridge.

\section{B. Radiological evaluation:}

Periapical and/or panoramic views were taken for all patients of both the control and the study groups.

All radiographic views showed signs of bone trabeculation in the previously empty sockets with varying signs of resorbing lamina dura from the walls of the sockets.

\subsection{Discussion}

Patients with acute leukemia undergoing chemotherapy treatment have prolonged thrombocytopenia because of the cytotoxic therapies they receive and because of their underlying disorders. There is a direct relationship between bleeding and thrombocytopenia that has been described. Therefore, bleeding is a very common complication occurring following chemotherapy in patients with acute leukemia in the dental field and is a major cause of morbidity and mortality in such patients $[10,11]$.

The goal of dental treatment in leukemic patients is to maintain the integrity of the oral mucosa, prevent secondary infections, provide relief, and maintain dietary intake. Dental infections cause oral and systemic complications during chemotherapy [12].

This study was conducted on 21 (16 males and 5 females) hospitalized patients suffering from acute leukemia with thrombocytopenia with an age range from 15-45 years and mean of age 33.57 years. They were selected in postinduction phase of chemotherapy. All patients had one or more tooth indicated for extraction with a total number of tooth extraction about 60 (, seventeen patients had acute myeloid leukemia and four patients had acute lymphoblastic leukemia.

The results of our study showed that males were more affected than females 16:5. Also, acute myeloid leukemia was more common than acute lymphoblastic leukemia among the age range, and males were more affected than females 17:4.

This agrees with Horner et al in 2008 who reported in the study carried from 2002-2006 on 12000 patients to provide statistical information about incidence and mortality rate of acute myeloid leukemia in U.S that acute myeloid leukemia was common and the adults and males (9452) were commonly affected than females (2548) [13]. 
In our study, patients were selected with platelet count not less than $50.000 / \mathrm{mm}^{3}$ and absolute neutrophil counts not less than $1000 / \mathrm{mm}^{3}$ to avoid the high bleeding tendency and opportunistic infections, this selection criterion followed the study of Dibiase in 1983 who stated that the aggressiveness of oral care must be compatible with the status of the patient's bone marrow. The patient's oral hygiene can be maintained if the platelet count is greater than $50,000 / \mathrm{mm}^{3}$ and the granulocyte count is at least $1000 / \mathrm{mm}^{3}$, when the platelet count is below $50,000 / \mathrm{mm}^{3}$, the use of floss, toothpicks, and water irrigating devices are contraindicated due to their potential for producing local trauma [14].

All patients in this study were given oral antibiotics one hour before the procedure as a prophylactic measure to prevent secondary infection. This was recommended by Brook in 2003 who stated that proper administration of prophylactic antibiotics for patients with nonsurgical cancer therapies will prevent secondary infection when the absolute granulocyte count is below $2000 / \mathrm{mm}^{3}$. The prophylactic antibiotics should be given and the dosage and duration should be determined after consultation with the hematologist/oncologist to avoid secondary infection [10].

In this study, patients were randomly allocated into three groups; group I Consisted of seven patients receiving platelet transfusion one hour before extraction to control post extraction bleeding. It is generally accepted that prophylactic or therapeutic platelet transfusion decreases the risk of bleeding in patients with acute leukemia [15,16]. However, despite the administration of prophylactic platelet transfusions, these patients remain at risk of clinically significant hemorrhage $[17,18]$, bacterial and viral infections and allergic reaction as anti-platelet antibody formation [19]. Group II consisted of seven patients where fibrin glue was used as a local hemostatic agent to control post extraction bleeding without the need for platelet transfusion. And group III consisted of seven patients where platelet glue was used as a local hemostatic agent to control post extraction bleeding without the need for platelet transfusion.

In group II using fibrin glue to achieve local homeostasis following dental extraction in patients with acute leukemia, diminishes the use of systemic replacement therapy and reduces severity of secondary hemorrhage. This is in agreement with Martinowitz at 1996 who states that the use of fibrin glue as a local hemostatic after dental extraction in 118 teeth in patients with bleeding disorders demonstrates the benefits regarding reduction of blood loss and diminishes the requirements for systemic replacement therapy and severity of secondary hemorrhage [20,21]. The clinical evaluation revealed immediate hemostasis and excellent result observed by using fibrin glue. This agreed with Suwannuraks et al in 1999 that used fibrin glue for tooth extraction in patients with hereditary or acquired bleeding disorders, immediate hemostasis was observed in all patients. Only one patient with hemophilia developed excessive postoperative bleeding [22]. $\mathrm{J}$ Huh et al in 2005 also reported that fibrin glue stimulates migration of neutrophils and increase the membrane's expression of $C_{11} \backslash C D_{18}$ receptors. These receptors permit adhesion of the neutrophil to the endothelium and fibrinogen as well as the transmigration of neutrophils [23]. Furthermore, Takata et al in 1995 and Dohan et al in 2006 who reported that fibrin glue acts as a scaffold sustaining the effect of anti-inflammatory and antibacterial agents [24-26].

In group III, the platelet concentrate was mixed with the fibrin glue to control post extraction bleeding. This is in agreement with Giannini et al in 2004 study who described the use of autologous platelet glue and bone fragments in maxillofacial surgery. Platelet glue had been used successfully in 5 patients who underwent surgery for maxillary or mandibular problems. The level of improvement was scored, arbitrarily, from 0 to 4 . Very favorable results were seen in those 5 patients. The glue preparation was very easy and inexpensive and the glue creates excellent and stable hemostasis. From a general point of view, they add additional anecdotal evidence supporting the utility of fibrin-platelet glue in terms of reduced infections and length of hospital stay, which suggest the need for wellplanned and controlled trials to show if there is benefit and when and this treatment modality should be used in maxillofacial surgery who found was very easy and inexpensive and the glue creates excellent and stable hemostasis and reduced infections and length of hospital stay [27]. Also in agreement with Borie E et al in 2015 study who found a better result than fibrin glue in wound healing as platelet concentrate accelerate the last steps of coagulation and also had a significant additional benefit in accelerating wound healing which is aided by the presence of high concentration of growth factors [28]. 
Using fibrin glue or platelet glue following dental extraction resulted in less postoperative pain and swelling. This agrees with Man D et al. in 2001, who stated that using fibrin glue and platelet glue in cosmetic surgical procedures involving the creation of flaps, such as face lifts, reduction mammaplasties, adorninoplasties, resulted in many advantages. These included shorter operating times, the elimination of the need for drains, a reduction in the need for compressive dressings, a reduction in pain and postoperative swelling, and improved wound healing with a resultant shorter recovery time [29].

\section{CONCLUSION}

From this study, we concluded that the action of blood banked Fibrin glue and blood banked platelet glue as a local hemostatic agent is very important also its sealant effect which prevents air or fluids to leak is a very useful for better control post-extraction bleeding, also it reduces operative time and prevents complications associated with extraction procedures (hemorrhage, fluid and or air leaks, fistula formations) which result in reduction of postoperative discomfort. Also showed a significant acceleration of soft tissue healing in leukemic patients who are liable to postoperative bleeding and infection. Presence of growth factors in the platelet glue may be the cause of promoting soft tissue healing.

\section{CONSENT}

All authors declare that informed consent was obtained from the patient (or other approved parties) for publication of this study.

\section{ETHICAL APPROVAL}

All authors hereby declare that all experiments have been examined and approved by the appropriate ethics committee and have therefore been performed in accordance with the ethical standards laid down in the 1964 Declaration of Helsinki."

\section{COMPETING INTERESTS}

Authors have declared that no competing interests exist.

\section{REFERENCES}

1. Peterson LJ, Ellis E, Hupp JR, Tucker MR. chapter 1, preoperative health status evaluation, in Contemporary Oral and Maxillofacial Surgery, Hupp J R., 4th Edition. 2003;2-3.
2. American Academy of Pediatric Dentistry, "Guideline on dental management of pediatric patients receiving chemotherapy, hematopoietic cell transplantation, and/or radiation. Journal of Pediatric Dentistry. 2013;35(5):E185-E193.

3. Faderl S, Talpaz M, Estrov Z, et al. The biology of chronic myeloid leukemia. NEngl Med. 1999;341:164-72

4. Davies JA, Grant PJ. Acquired bleeding disorders. In: Management of bleeding patients in surgical practice. Eds: Forbes CD, Cushieri A. Blackwell Scientific Publications, Oxford. 1993;46-67.

5. Dzieczkowski JS, Anderson KC. Transfusion biology and therapy, in Harrison I, Randolph T, Isselbacher K (eds): Harrison's Principles of Internal Medicine (ed 14). New York, NY, McGrawHill. 1994;718-724.

6. Radosevich M, Goubran HA, Burnouf $T$. Fibrin sealant: Scientific rationale, production methods, properties, and current clinical use. Vox Sang. 1997;72(3): 133-43.

7. Jackson MR, MacPhee MJ, Drohan WN, Alving BM. Fibrin sealant: Current and potential clinical applications. Blood Coagul Fibrinolysis. 1996;7(8):737-46.

8. Burnouf T, Radosevich M, Goubran HA. Local hemostatic blood products: Fibrin sealant and platelet geL. World Fedration of Haemophilia. 2004;36.

9. Weibrich G, Kleis WK, Hafner G, et al. Comparison of platelet, leukocyte, and growth factor levels in point-of-care platelet-enriched plasma, prepared using a modified Curasan kit, with preparations received from a local blood bank. Clin Oral Implants Res. 2003;14(3):357-62.

10. Williford K, Salisbury PL, Peacock JE, Cruz JM, Powell BL, Lyerly ES, RL Capizzi $\mathrm{RL}$. The safety of dental extractions in patients with hematologic malignancies. Journal of Clinical Oncology. 1989;7(6): 798-802.

11. Koulocheris $P$, Metzger MC, Kesting MR, Hohlweg Majert B. Life-threatening complications associated with acute monocytic leukaemia after dental treatment. Australian Dental Journal. 2009;54(1):45-48.

12. Porcu P, Cripe L, Ng E. Hyperleukocytic leukemias and leukostasis: A review of pathophysiology, clinical presentation and management. Leuk Lymph. 2000; 39:1-18. 
13. Horner MJ, Ries LAG, Krapcho M, Neyman N, Aminou R, Howlader N, Altekruse SF Feuer EJ, Huang L, Mariotto A, Miller BA, Lewis DR, Eisner MP, Stinchcomb DG, Edwards BK (eds). SEER Cancer Statistics Review, 1975-2006. National Cancer Institute. Bethesda, MD, based on November 2008 SEER data submission, posted to the SEER web site; 2009.

Available:http://seer.cancer.gov/csr/1975 2006/

14. Dibiase CG, Komives BK. An oral care protocol for leukemic patients with chemotherapy-induced oral complications. Spec Care Den. 1983;3:207-13.

15. Pisciotto PT, Benson K, Hume $H$, Glassman AB, Oberman $H$, Popovsky $M$, et al. Prophylactic versus therapeutic platelet transfusion practices in hematology and/or oncology patients. Transfusion. 1995;35:498-502.

16. Fillmore WJ, Leavitt BD, Arce K. Dental extraction in the thrombocytopenic patient is safe and complications are easily managed. J Oral Maxillofac Surg. 2013; 71(10):1647-52.

DOI: 10.1016/j.joms.2013.05.011

Epub 2013 Aug 8

17. McCullough J, Vesole DH, Benjamin RJ, Slichter SJ, Pineda A, Snyder E, et al. Therapeutic efficacy and safety of platelets treated with a photochemical process for pathogen inactivation: The sprint trial. Blood. 2004;104:1534-41.

18. Cocero N, Bergamasco L, Mozzati M. Oral surgery procedures in patients with severe thrombocytopenia. The use of platelet concentrates instead of platelet transfusion. Casecontrol comparison between the two methods. Int Dent Res. 2012;2:27-32.

19. Ogle OE. Perioperative hemorrhage. In: Dym $\mathrm{H}$, Ogle OE. Atlas of minor oral surgery. Philadelphia, Pa: WB Saunders; 2000;62-63.

20. Martinowitz $U$, Schulman S. Fibrin sealant in surgery of patients with a hemorrhagic diathesis. Thromb Haemost 1995;74(1): 486-92.

21. Martinowitz U, Schulman S, Horoszowski $\mathrm{H}$, Heim M. Role of fibrin sealants in surgical procedures on patients with hemostatic disorders. Clin Orthop. 1996; 328:65-75.

22. Suwannuraks $M$, Chuansumrit $A$, Sriudomporn N. The use of fibrin glue as an operative sealant in dental extraction in bleeding disorder patients. Haemophilia. 1999;5:106-8.

23. J. Huh, B. Choi, S. Zhu, J. Jung, S. Lee, T. You, H. Lee, J. Li. The use of autologous fibrin glue for closing sinus membrane perforations during sinus lifts. 2005;101: 150-4.

24. Takata $\mathrm{T}$, katauchi $\mathrm{K}$, Miyauchir M, Ogawa I, Akagawa Y, Nikail T. Periodontal tissue regeneration on the surface of synthetic hydroxy apatite implanted into the root surface. J Periodontal. 1995;66-125.

25. Dohan DM, Choukroun J, Diss A, Dohan SL, Dohan AJJ, Mouhyi J, Gogly B. Platelets rich fibrin: Asecond-generation platelet concentrates. Part III: leukocyte activation: A new feature for platelet concentrates. Oral Surg. 2006;101(3):51-5.

26. Dohan DM, Choukroun J, Diss A, Dohan SL, Dohan AJJ, Mouhyi J, Gogly B. Platelets rich fibrin: Asecond-generation platelet a Part I: Technological concepts and evolution. Oral Surg Oral Med Oral Path Oral Radiol Endod. 2006;101:E37-44.

27. Gabriella Gianninia, Valbonesi Mauroa, Tel Agostinob, Bindi Gianfranco. Use of autologous fibrin-platelet glue and bone fragments in maxillofacial surgery. J. Transci. 2004;30(2):139-144.

28. Borie E, Oliví DG, Orsi IA, Garlet K, Weber $B$, Beltrán $V$, et al. Platelet rich fibrin application in dentistry: A literature review. Int J Clin Exp Med. 2015;8:7922-9.

29. Man D, Plosker HE, Winland-Brown J, Raton B. The use of autologous plateletrich plasma (platelet gel) and autologous platelet-poor plasma (Fibrin Glue) in cosmetic surgery. Plastic \& Reconstructive Surgery. 2001;107(1):229-37.

(0) 2017 Salem and Saad; This is an Open Access article distributed under the terms of the Creative Commons Attribution License (http://creativecommons.org/licenses/by/4.0), which permits unrestricted use, distribution, and reproduction in any medium, provided the original work is properly cited.

Peer-review history:

The peer review history for this paper can be accessed here: http://sciencedomain.org/review-history/19119 